UDC 911.5:913 (477.44)

Anatoliy Vasyliovich Hudzevich,

Doctor of Sciences (Geography), Professor, Department of Geography,

Vinnytsia Mykhailo Kotsiubynskyi State Pedagogical University,

32 Ostrozhskoho St., Vinnytsia, 21001, Ukraine,

e-mail: amarek@ua.fm, https://orcid.org/0000-0001-8884-9436;

Vasyl Yevhenijovich Liubchenko,

$\mathrm{PhD}$ (Geography), Head of the Research Department of the Karmelyukove Podillya National Nature Park,

15 Sviato-Mikhailivskia St., Chechelnyk village, 24800, Vinnytsia region, Ukraine,

e-mail: vasalve@gmail.com, https://orcid.org/0000-0002-1871-5341;

Lina Fedosiivna Bronnikova,

Senior Lecturer (Agriculture), Department of Agriculture, Soil Science and Agrochemistry

Vinnytsia National Agrarian University, 3 Soniachna St., Vinnytsia, 21100, Ukraine,

e-mail: linabronnikova@gmail.com, https://orcid.org/0000-0002-1790-161X;

Ludmila Serhiivna Hudzevich,

$\mathrm{PhD}$ (Biology), Associate Professor, Department of Biology,

Vinnytsia Mykhailo Kotsiubynskyi State Pedagogical University,

e-mail: gudzevichluda@gmail.com, https://orcid.org/0000-0002-7631-7704

\title{
LANDSCAPE APPROACH TO REGIONAL FEATURES ORGANIZATION OF ENVIRONMENTAL MANAGEMENT OF THE PROTECTED AREA
}

\begin{abstract}
А. В. Гудзевич, В. С Любченко, Л. Ф. Броннікова, Л. С. Гудзевич. ЛАНДШАФТНИЙ ПІДХІД ДО ВРАХУВАННЯ РЕГІОНАЛЬНИХ ОСОБЛИВОСТЕЙ ОРГАНІЗЦІЇ ПРИРОДОКОРИСТУВАННЯ ПРИРОДООХОРОННОӤ ТЕРИТОРІЇ. Розглянуто використання ландшафтного аналізу в якості інструменту для виявлення регіональних особливостей територіальної організації природокористування природоохоронної території рівня начіонального природного парку. Показано можливості використання ландщафтної основи в оцінці та визначенні иілей при перспективному плануванні природоохоронної діяльності, зокрема на територіях, які асоціюється із землями запасу та мають иінне природоохоронне значення ŭ перебувають під постійною загрозою інтенсивного негативного антропогенного впливу. Результатом застосування ландшафтного аналізу є встановлення великої різноманітності рівнинних Східноєвропейських ландшафтів Правобережного лісостепу, які диференціюються не тільки за типами та їх широтними (зональними) й аширотними (інтразональними) варіантами, але й з врахуванням їх тривалого господарського освоєння. Використано поєднання типологічного і регіонального підходів до показу нижніх рівнів ландшафтної структури із складанням ландмафтної характеристики території, проектованої до розширення та передачі в постійне користування до складу НПП «Кармелюкове Поділля» та ї̈ відображення на ландшафтній карті. Наведена ландшафтна карта демонструє закономірності територіальної диференціаціі господарської зони природоохоронного середовища і відображає різні форми ї̈ структури за антропогенно-ландмафтною різноманітністю. На ній зафіксовано: заміщення широтно-типових лісостепових ландшафтів різногенезисними антропогенними варіантами - сільськогосподарського, лісогосподарського, водогосподарського, природоохоронного та шляхового класів антропогенних ландшафтів; окрім типологічних підрозділів високого рівня (класів і типів ландшафтів), представлено 33 види урочищ, які є наразі найбільш типовими виділами ландшафтів ділянок дослідження. Відомості про територіальну структуру і фізіономічні риси ландшафтних комплексів начіонального природного парку, отримані при ландшафтному картографуванні, можуть бути інтерпретовані з позичій прикладної географї шляхом застосування методів ландшафтного планування найближчим часом.
\end{abstract}

Ключові слова: ландшафтний аналіз, національний природний парк, ландшафтна карта, антропогенні ландшафти, урочища типів місиевості.

А. В. Гудзевич, В. Е. Любченко, Л. Ф. Бронникова, Л. С. ГУдзевич. ЛАНДШАФТНЫЙ ПОДХОД К УЧЕТУ РЕГИОНАЛЬНЫХ ОСОБЕННОСТЕЙ ОРГАНИЗАЦИИ ПРИРОДОПОЛЬЗОВАНИЯ ПРИРОДООХРАННОЙ ТЕРРИТОРИЕЙ.

Рассмотрено использование ландшафтного анализа в качестве инструмента для выявления региональных особенностей территориальной организации природопользования природоохранной территории уровня национального природного парка. Показаны возможности использования ландиафтной основы в оценке и определении целей при перспективном планировании природоохранной деятельности, в частности на территориях, которые ассоциируются с землями запаса, имеют иенное природоохранное значение и находятся под постоянной угрозой интенсивного негативного антропогенного воздействия. Результатом применения ландшафтного анализа является установление большого разнообразия равнинньх восточноевропейских ландшафтов Правобережной лесостепи, которые дифференцируются не только по типам и их ииротными (зональными) и аширотными (интразональными) вариантами, но и с учетом их длительного хозяйственного освоения. Использовано сочетание типологического и регионального подходов к показу нижних уровней ландшафтной структурьл с составлением ландшафтной характеристики территории, проектируемой к расширению и передачи в постоянное пользование в состав НПП «Кармелюково Подолье» и ее отображения на ландшафтной карте. Приведенная ландиафтная карта демонстрирует закономерности территориальной дифференциации хозяйственной зонь природоохранного среды и отражает различные формы ее структуры с антропогенно-ландшафтным разнообразием. На ней зафиксировано: замещение широтно-типических лесостепных ландшафтов разного генезиса антропогенными вариантами - сельскохозяйственного, лесохозяйственного, водохозяйственного, природоохранного и дорожного классов антропогенных ландиафтов; кроме типологических подразделений высокого уровня (классов и типов ландшафтов), представлено 33 вида урочищ, которые являются сейчас наиболее типичными ландшафтными образованиями участков исследования. Сведения о территориальной структуре и физиономические черты ландиафтных комплексов национального природного парка, полученные при ланд-

(C) Hudzevich A.V., Liubchenko V.Ye., Bronnikova L.F., Hudzevich L.S. https://doi.org/10.26565/2410-7360-2020-52-09 
шафтном картографировании, могут быть интерпретированы с позиций прикладной географии путем применения методов ландшафтного планирования в ближайшее время.

Ключевые слова: ландшафтный анализ, начиональный природный парк, ландшафтная карта, антропогенные ландшафты, урочища типов местности.

Problem Statement. For the first time in the half-century of Davos Economic Forum, it has been identified that the world's five largest risks are environmental. It is about climate disasters, loss of biodiversity and the destruction of terrestrial and aquatic ecosystems $[1,2]$. According to the United Nations Environment Program, UNEP, more than 12\% of the land surface is now protected. In the EU countries, the most valuable territories are protected by the Nature 2000 network, which is formed by 27393 sites with a total area of $1106612.96 \mathrm{~km}^{2}$, including terrestrial $788487.39 \mathrm{~km}^{2}$ or $18 \%$ of the EU land area [3]. The highest indicator of nature conservation areas of the European community is in Poland - more than 33\%. The current overall indicator of nature protection of Ukraine $-6.73 \%$ is significantly inferior to the European norm. Ukraine, taking a course to bring the state of the environment in line with European standards, also requires the expansion of the NCF (nature conservation fund). The estimated area of the NCF of Ukraine should reach $15 \%$ from the state area [4].

Within the regions, the percentage of land conservation is in the range of $0.9 \%$ to $14.8 \%$ [5]. In particular, in Vinnytsia region as of 01.01.2020 there were 427 territories and objects with a total area of more than 66 thousand hectares. The NCF consists of 43 territories of national importance, of which 1 is a national nature park and 381 of local importance, of which 4 are regional landscapes. But despite the significant number of nature conservation areas and sites, Vinnytsia Oblast occupies only $2.5 \%$ of the area and one of the last places in Ukraine by conservation area. The urgent issue of expanding the PFP area can be solved in two ways: by creating new objects and territories or by joining existing conservation areas. Let us note the prospect of the second option, in particular, the expansion of the area of the PZF region by joining valuable territories adjacent to the only one in the area of the «Karmelyukovo Podillya» National Nature Park (NNP).

\section{Analysis of recent research and publications.}

Awareness of the territorial planning importance in terms of landscape approach was the adoption in 2000 of the European Landscape Convention (entered into force on 1 March 2004) [6]. It legally enshrines the term "landscape", indicates the particular value of landscapes to ensure conditions for transition to sustainable development, and the quality and diversity of landscapes are considered a valuable pan-European resource that defines the quality of life of the population, are the basis of cultural heritage and social well-being.

Landscape approach, in the current state of geographic studies, is defined as a basic operation and an algorithmic method of research in determining the territorial organization of land [7].

Its main essence is determined in the orientation to rank taxonomic and individual-typological diversity and complex representativeness [8], which by means of mapping makes it possible to obtain detailed information about the spatial structure of the nature management of the study region [9-11].

Particular attention is paid to the work of Ukrainian geographers, which justifies the selection of specific structural and geographical directions landscape-ecological and regional landscape planning, as a system of measures aimed at environmentally balanced organization of nature management in the territories of different local levels of organization of the environmental [12-13].

There is some experience in identifying features of the processes of anthropogenic transformation of modern landscapes of Ukraine, which makes it possible to carry out geo-ecological substantiation of the system of environmental measures [14] and to conduct a regional analysis of the assessment of existing conditions for the creation of nature protection territories.

In particular, for the purpose of development and improvement of the existing network of nature reserves of the region in 1997 by the employees of the interdepartmental complex laboratory of scientific bases of the NAS and Ministry of ekosecurity of Ukraine (Doctor of Biological Sciences T.L. Andrienko, Y.P. Didukh and Candidate of Biological Sciences G.A. Chorna, M.M. Fedorochuk) a preliminary scientific substantiation was made regarding the feasibility of establishing in the southeast of the Vinnytsia region of the Chechelnitsky National Natural Park a total area of about 52 thousand hectares [15].

In 1998 employees of the departments of physical geography and natural sciences of Mykhailo Kotsyubynsky Vinnitsa State Pedagogical University and Vinnytsia Cartographic Factory under the direction of Candidate of Geographic Sciences A.V. Gudzevich continued research work to ensure preparation of materials for creation of multifunctional nature reserve in the specified territory [16]. The personification of the territory of the projected NNP of the South Podillya, which they noted, gave the basis for fixing the name "South Podillya" or "South Podilsky" for this nature-protected object [17]. 
From 2006 till now the scientific surveys of the territory have continued: botanical - Ph.D. A.A. Kuzemko, V.I. Melnyk, Ph.D. I.O. Skoroplyas, O.O. Shinder, N.A. Pashkevich, O.Z. Petrovich, A.S. Drapaluk, E.O. Vorobyova and biologists Yavorskaya O.G., Vorona E.I.; zoological - Ph.D. V.A. Gorobchishin, Yu.O. Google, P.C. Svitin, O.D. Nekrasova, O.A. Matviychuk, M.Yu. Rusin, O.O. Chovan, D.I. Ocheretnyy. Instead, geographical and cartographic studies were carried out sporadically $[15,18,19]$. The problem of establishing the landscape structure of both, the park area, and the adjacent, above all valuable in nature protection plan is an urgent task of today. It should be noted that the optimization of the Park territory with the extension of its borders is carried out in accordance with the Project of the territory organization of the «Karmelyukovo Podillya» National Nature Park [20], whose main task is to increase the area of the NNP territory at the expense of valuable adjacent lands.

Aim, object and methods of research. The purpose of the study is to use landscape analysis as a tool for identifying regional features of the territorial organization of nature conservation of the level of the national nature park as a future basis for the long-term planning of environmental activities. Landscape analysis, characterized by complexity, and therefore allows to establish the specificity of landscapes, their structural features to form the most complete idea of the territory as a complex [21, 22-25].

The object of study is Vyshenka tract and adjacent lands, mostly associated with stock lands, which are of environmental value and are under constant threat of intense negative anthropogenic influence (fig. 1).

Field observations $[26,27]$ were used to form a general picture of landscape cognition and to identify the specific nature of the region, while for the visualization of the data obtained - mapping [28, 29] and spatial-graphical modeling [30-32].

Exposition of the main research material. National Natural Park «Karmelyukove Podillya» is one of 55 in Ukraine of this type. It is located on the territory of the southeastern part of Vinnytsia region, covers the south of Chechelnytsky and Trostyanets districts, and borders the Kodyma and Balta regions of Odeschyna [5].

The total area of the NNP is 20203.4 hectares of state-owned land, including 16.518 hectares of land of the state-owned enterprise Chechelnytsky Forestry, which is provided to the Park for permanent use and 3,685.4 hectares of land that is included in it without deletion from land users.

There are a number of adjacent valuable sites in the area of Karmelyukovo Podillya NNP, which remained in a relatively untouched natural state, where forest, steppe, meadow and wetland vegeta-

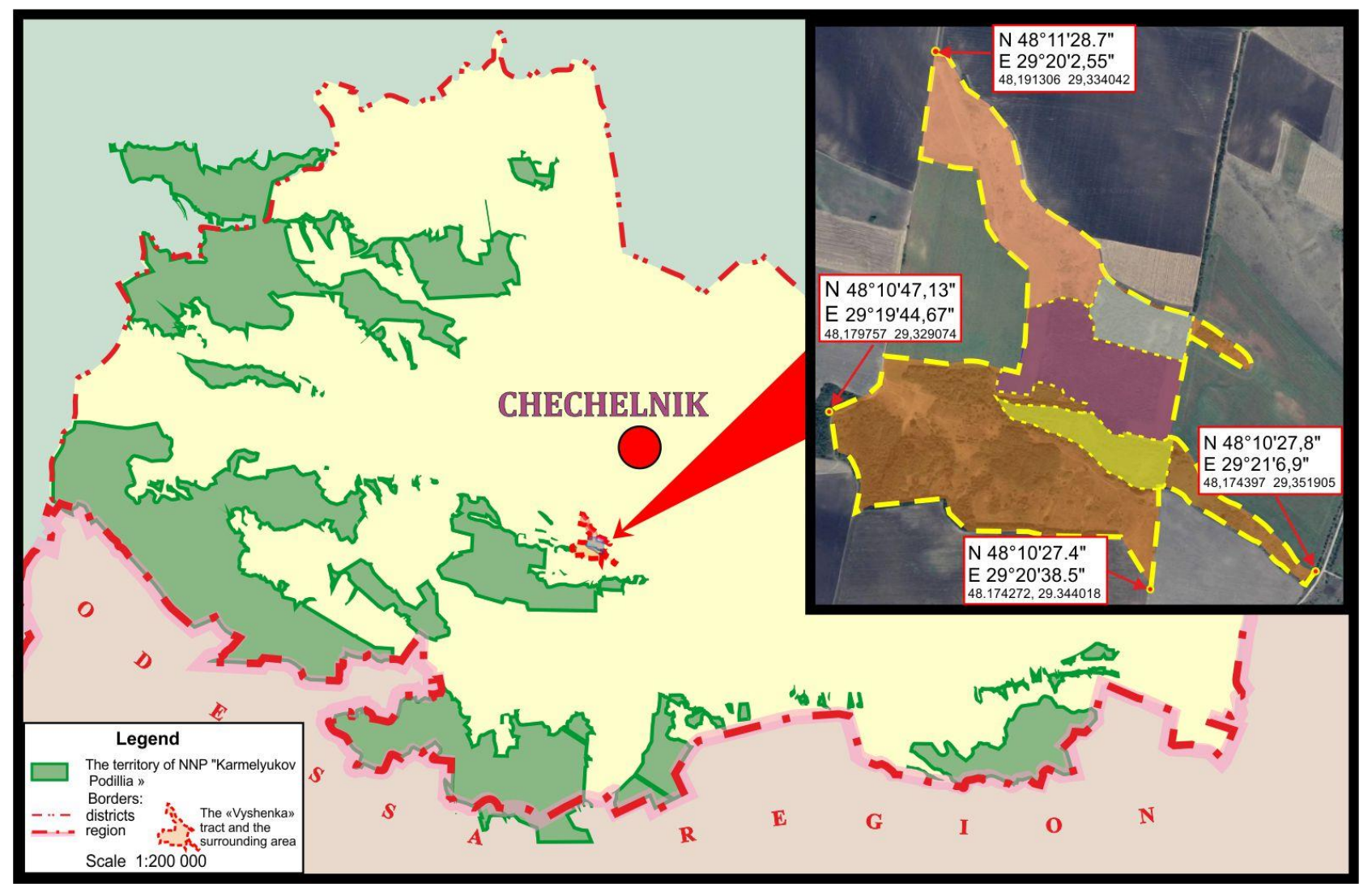

Fig. 1. The «Vyshenka» tract and adjacent territories against the background of the Karmelyukove Podillya National Park 
tion with a sufficiently rich fauna gene pool is represented. These territories are of particular value for the protection of the environment, the conservation of, first and foremost, the species of plants and animals included in the Red Book of Ukraine and plant communities included in the Green Paper of Ukraine.

Among the promising territories that are envisaged to be included in the NNP with the right of permanent use, are the terrain within the Chechelnytsia settlement council of the Chechelnytsia district of Vinnytsia region. In local land users, it is known as the "Vyshenka" tract, covering an area of 46.2 ha. Its peculiarity is that it is surrounded by intensively used agrocenoses and is part of the economic zone of the NNP with a total area of 110.9 hectares within the Chechelnytsia settlement council (fig. 2). The lands are included, according to functional zoning [17] and the project of creation of NNP "Karmelyukovo Podillya" without its removal from the user (Decree of the President of Ukraine of December 16, 2009 No. 1057/2009). At present, $18.3 \mathrm{hec}$ - tares of the designated area is in constant use of the state enterprise Chechelnytsky Forestry [20].

Belonging to the economic zone of the NNP presupposes the traditional management of the economy in compliance with environmental legislation. Currently, there are a number of violations: poaching, burning of grass and tree vegetation, illegal felling of trees, contamination of the territory with household waste, plowing of meadow-steppe areas for crops of agro-crops, destruction of plants and plant communities included in the Red (Carlina onopordifolia Besser ex Szafer, Kulcz. et Pawt, Stipa capillata L. and Sorbus torminalis (L.) Crantz) and Green Book Ukraine (Festuco valesiacaeStipetum capillatae Sillinger 1930). In addition, the proximity of the tract «Vyshenka» to the village of urban type Chechelnyk, which leads to its constant use as a resting place of the population, is marked by constantly increasing negative anthropogenic influence and there is a threat of impoverishment of the biodiversity of this territory.

According to the physical-geographical zoning

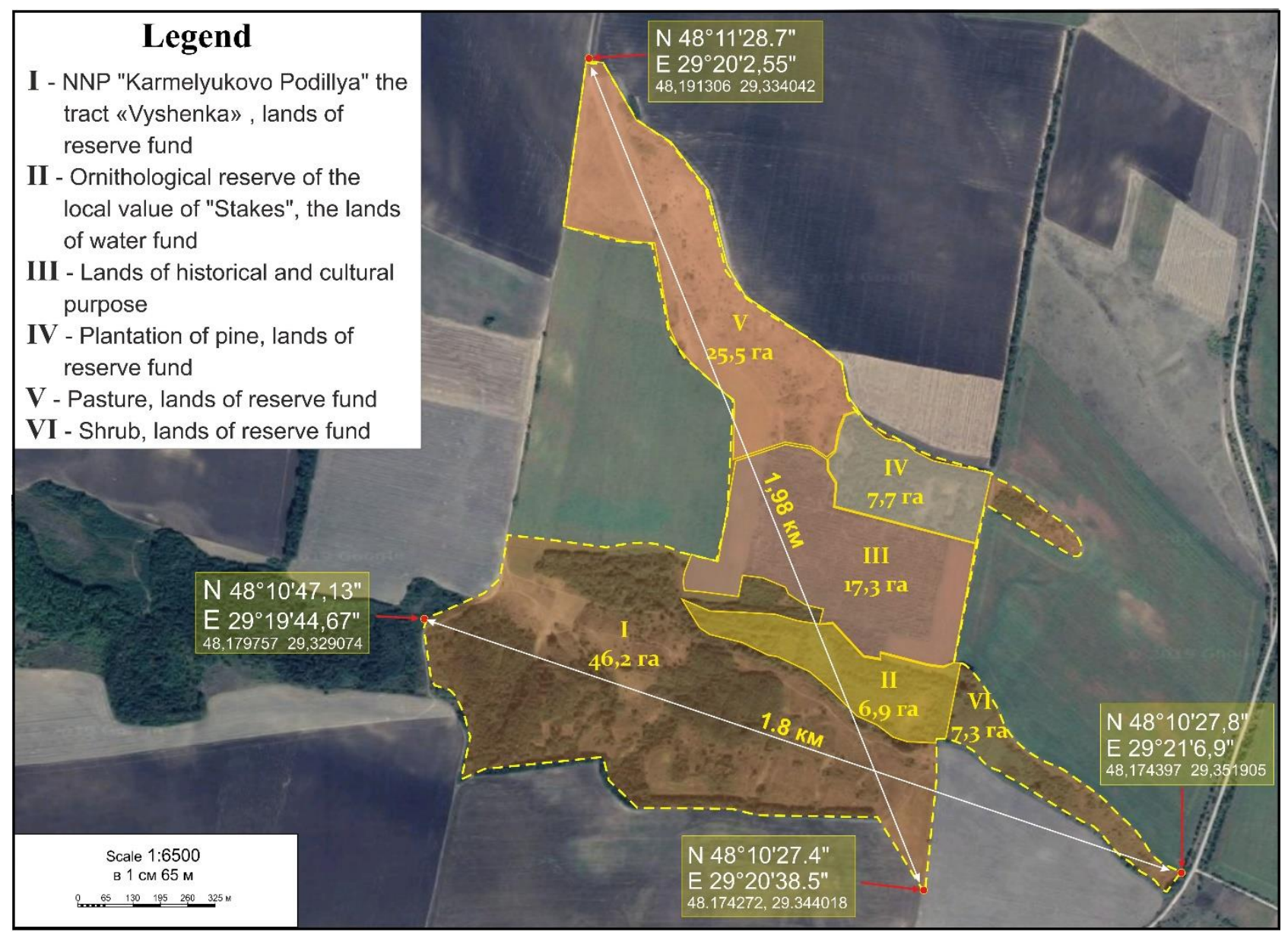

Fig. 2. Land use structure of promising territory for inclusion in NNP "Karmelyukovo Podillya"

of Ukraine the territory of the Vyshenka tract and the surrounding lands is included in the Balt-Savran district of the South Podilsky upland region of the Podilsky-Prydniprovsky region, which is part of the Forest-steppe zone of Ukraine [33].
In geostructural terms, this site belongs to the southwestern slope of the Ukrainian Crystal Shield. According to the geobotanical zoning of Ukraine it belongs to Podilsky-Seredneprydniprovsky subprovince of the Eastern European province of the 
European-Siberian forest-steppe region and is located in the Kodymo-Savransky district of rocky oak and common oak forests, southern variant of meadow steppes of the Yampil'-Ananiv district, meadow steppes and vegetation of limestone outcrops [15].

Structurally and typologically, the territory of the Karmelyukove Podillya National Park, which is promising to be expanded, belongs to the class of flat Eastern European landscapes [33], which are differentiated by types and their latitudinal (zonal) and no-latitudinal (intrazonal) variants. According to the latitudinal and typological aspect, the territory is forest-steppe. General background of the foreststeppe complexes is formed by landscapes of elevated forest plains, strongly indented by ravines and gullies, with black podzoil soil. This type of landscapes is a consequence of the active development of erosion-denudation processes within the most hypsometrically elevated in the studied territory of the south-eastern spurs of the Podolsk upland. Wideundulating longitudinal watershed and slope, mainly ploughed types of terrain, are dominant among the landscapes of this species. There are also weakly wavy finite-watershed and flat-plan watershed types of subordinate importance. They only outline the study area. The forest-steppe type includes three subtypes of landscapes: broad-leaved forest, lowdensity forest of forest steppe, and meadow-step- pe [34].

The basis of the territory under analysis is two long, wide and deep enough $(30-50 \mathrm{~m})$ gullies, which merge to give the surface of a bumpy-gully view and provide dominance in their composition of the bumpy-gully watershed type of the terrain with podzolic chernozems on gully under the meadowshrub and forest vegetation.

The peculiarity of the manifestation and distribution of landscapes types is caused by the fact that the areas of their location are intersected by intrazonal anthropogenic landscape complexes (LC). Formation of anthropogenic LC is mainly related to nature uses such as forestry and agriculture (forestation, gardening, crop rotation fields and grassland). Other areas, such as transportation, agriculture and environmental protection, are of ancillary character.

The consequence of age-old human activity is the complete replacement of latitudinal vegetation type (deciduous forests and meadow steppes), change of soil cover and its physicochemical properties and formation of different classes of anthropogenic agricultural landscapes with subclasses (field, meadow-pasture, orchard or perennial plantings), forestry, water economic nature conservation and road (fig. 3).

Rural landscapes or agricultural landscapes. There are several subclasses - field, meadow-pastu-

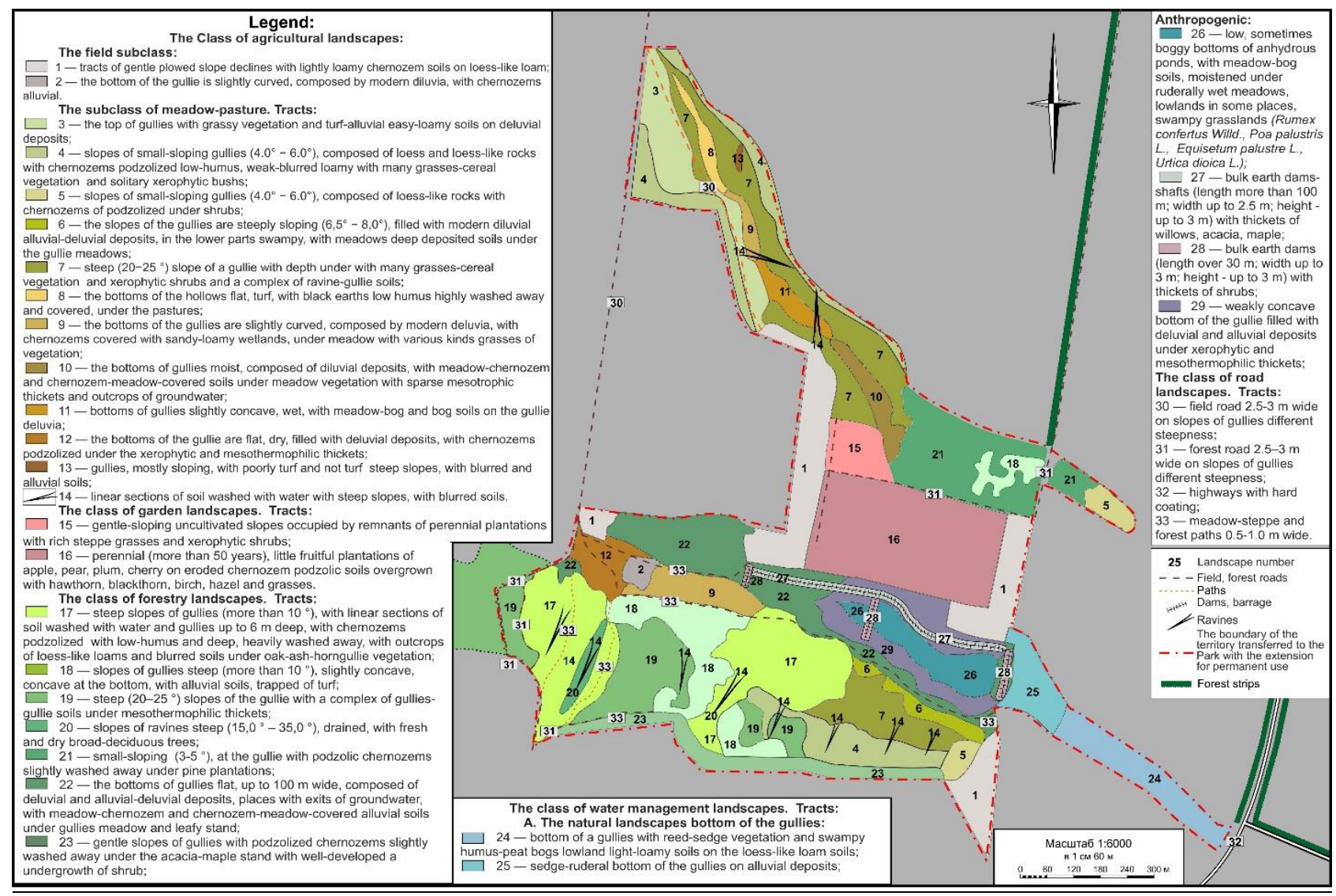

Fig. 3. Structural organization and diversity of typological landscapes perspective territory for inclusion in the Karmelyukove Podillya National Park prospective territory for inclusion in Karmelyukove Podillya National Park 
re, orchard.

The fields are represented by inclined ploughed sloping slopes with lightly loamy chernozem soils on woody loam on either side of the gullie (see fig. 3 ). In fact, they are a kind of ecotone of the surrounding land, according to their intended purpose

The meadows-pastures in the most holistic form are confined to the reserve lands (25.5 ha), the bottoms of gullies, as well as the southeast slope of the «Vyshenka» tract. The tracts dominate:

1 - Tops of gullies with grasses-cereal vegetation and turf-alluvial light loamy soils on deluvial deposits;

2 - slopes of slightly sloping gullies $\left(4.0^{\circ}-6.0^{\circ}\right)$, composed of loess and loess-like soil types with black soil of podzolized and low-humus and scantily washed away loam and of the light loam;

3 - the slopes of the gullies are steeply sloping $\left(6,5^{\circ}-8,0^{\circ}\right)$, filled with modern deluvial, alluvialdeluvial deposits, in the lower parts swampy in some places, with meadow deep alluvial soils under the gully meadows;

4 - steep slope of the gully $\left(20-25^{\circ}\right)$ with multifaceted grasses-cereal vegetation and a complex of ravine-gully soils;

5 - the bottoms of the hollows flat, turf, with black earths with low humus, highly washed away and covered, under the pastures;

6 - the bottoms of the gullies are slightly curved, composed by modern deluvial, with chernozems covered with sandy-loamy wetlands, under meadow with various kinds grasses of vegetation;

7 - the bottoms of gullies moist, composed of deluvial deposits, with meadow-chernozem and chernozem-meadow-covered soils under meadow vegetation with sparse mesotrophic thickets and outcrops of groundwater;

8 - bottoms of gullies slightly concave, wet, with meadow-bog and bog soils on the gullies deluvia;

9 - the bottoms of the gullies are flat, dry, filled with deluvial deposits, with chernozems podzolized under the xerophytic and mesothermophilic thickets;

10 - gullies, mostly sloping, with poorly turf and not turf steep slopes, with blurred and alluvial soils;

11 - linear sections of soil washed with water with steep slopes, with blurred soils.

Garden landscapes of the study area are confined to the lower slopes of the left side of the gullies. The tracts dominate:

1 - gentle-sloping uncultivated slopes occupied by remnants of perennial plantations with rich steppe grasses and xerophytic shrubs;

2 - perennial (more than 50 years), little fruit ful plantations of apple, pear, plum, cherry on eroded chernozem podzolic soils overgrown with haw- thorn (Crataegus monogyna Jacg.), blackthorn (Prunus spinosa L.), birch (Betula pendula Roth), hazel (Corylus avellana L.) and grasses;

Class of forestry landscapes. The conditions of plowing (slope surfaces, gully-ravine network), complicated by the relief, determined the relatively high afforestation of the studied landscape. Forest crops created in deforestation and previously deforested areas occupy large areas (about 50 hectares) within the "Vyshenka» tract and on the left slope of the gullies, near the old garden. In some cases, logging areas preceded by newly created forest landscapes are covered with steppe vegetation or low-value tree species, most commonly acacia (Acacia). The variety of ways of creating self-healing forest landscapes requires the development of a classification scheme for their genesis, which may be one of the tasks of scientific knowledge of the area in the future. All modern forest complexes are represented by two subclasses: conditionally natural, renaturalized and anthropogenic forest landscapes.

The first subclass includes self-healing overgrowths and seed landscapes. The second is forestry and primary-derived landscapes.

The tracts dominate:

1 - steep slopes of gullies (more than $10^{\circ}$ ), with linear sections of soil washed with water and gullies up to $6 \mathrm{~m}$ deep, with chernozems podzolized with low-humus and deep, heavily washed away, with outcrops of loess-like loams and blurred soils under oak-ash-horngullie vegetation;

2 - slopes of gullies steep (more than $10^{\circ}$ ), slightly concave, concave at the bottom, with alluvial soils, trapped of turf;

3 - slopes of ravines steep $\left(15,0^{\circ}-35,0^{\circ}\right)$, drained, with fresh and dry broad-deciduous trees;

4 - small-sloping $\left(3-5^{\circ}\right)$, at the gullie with podzolic chernozems slightly washed away under pine (Pinus L.) plantations;

5 - the bottoms of gullies flat, up to $100 \mathrm{~m}$ wide, composed of deluvial and alluvial-deluvial deposits, places with exits of groundwater, with meadow-chernozem and chernozem-meadowcovered alluvial soils under gullies meadow and leafy stand;

Class of water management landscapes occupies more than 10 hectares and are represented by forested, meadow-stepped and meadow-swamp complexes within the ornithological reserve of the local pond (6.9 hectares; see fig. 2) and the northeastern suburbs of the «Vyshenka» tract.

Typical types of tracts are the bottoms of gullies with ruderal and wetland vegetation and sodcovered silt-loamy soils on the deluvial deposits. The surface of the tract is flat, complicated by artificial shafts and dikes. There are streams of temporary watercourses, near which the bottoms are heavily 
wetland. Tracts outside the reserve are most commonly used under pastures. The vegetation is dominated by sedge-ruderal and shrub-sedge associations, there are small thickets of willow (Salix cinerea L., S. caprea L., S. viminalis L., S. acutifolia Willd.), acacia yellow (Caragana arborescens Lam.) and white (Robinia pseudoacacia L.), maple (Acer negundo L.).

The tracts dominate:

The Natural landscapes bottom of the gullies:

1 - the bottom of a gully with reed-sedge vegetation and swampy humus-peat bogs lowland lightloamy soils on the loess-like loam soils;

2 - sedge-ruderal bottom of the gullies on alluvial deposits;

Anthropogenic transformed landscapes:

1 - low, sometimes boggy bottoms of anhydrous ponds, with meadow-bog soils, moistened under ruderally wet meadows, lowlands in some places, swampy grasslands (horse sorrel Rumex confertus Willd., thin-footed marsh Poa palustris L., marsh horsetail Equisetum palustre L., nettle Urtica dioica $\mathrm{L}$.);

2 - bulk earth dams-shafts (length more than $100 \mathrm{~m}$; width up to $2.5 \mathrm{~m}$; height - up to $3 \mathrm{~m}$ ) with thickets of willows (Salix acutifolia Willd., $S$. caprea L., S. cinerea L., S. viminalis L.), acacia yellow (Caragana arborescens Lam.) and white (Robinia pseudoacacia L.), maple (Acer negundo L.).

3 - bulk earth dams (length over $30 \mathrm{~m}$; width up to $3 \mathrm{~m}$; height - up to $3 \mathrm{~m}$ ) with thickets of shrubs;

Naturally, hydrotechnical landscapes are artificial entities and require human monitoring and intervention to maintain such landscapes in a stable state. Now artificial reservoirs are subject to cover with silt, overgrowning.

Class of road landscapes.

Forest-steppe (natural landscapes) and forestfield and forest-pasture (anthropogenic landscapes) types of road landscapes are presented.

The tracts dominate:

1 - field road 2.5-3 m wide on slopes of gullies with different steepness

2 - forest road 2.5-3 m wide on slopes of gullies different steepness

3 - highways with hard coating

4 - meadow-steppe and forest paths $0.5-1.0 \mathrm{~m}$ wide.

Environmental protection landscape is represented by an ornithological reserve of the local value of the «Ponds» (6.9 ha). The most common in their composition is the undrained type of terrain of wetted (wetland) parts of the bottom of the gully. The slightly drained terrain type of low periodically flooded floodplains is slightly less represented and only a small proportion (about 5\%) is the drained terrain type of high floodplains and dams. In the structure of vegetation of meadow floodplains, floodplain meadows dominate: cereals, grasses and sedges; forest subtypes of the landscape are characterized by willows (Salix cinerea L., S. caprea L., $S$. viminalis L., S. acutifolia Willd.), acacia yellow (Caragana arborescens Lam.) and white (Robinia pseudoacacia L.), maple (Acer negundo L.). In the moistened reductions in the relief of development, grass, sedge, hypno-sedge and reed-sedge swamps acquired. The list of dominant tracts is given when characterizing water management landscapes.

Conclusions. Karmelyukove Podillya NNP is located in the southeastern part of Vinnytsia region. Within its economic zone and adjacent lands there are a number of valuable sites that are of particular conservation value.

The research confirmed the need to organize rational use of nature and protection of landscape and biodiversity of the territory, which, according to the project of creation of the Park, was included in the NNP "Karmelyukovo Podillya" without removal from the user, in order to preserve it and balanced development as a complete landscape system. Landscape-cartographic approach, carried out by the application of the expedition method, allowed to fix the replacement of latitudinal-typical forest-steppe landscapes with different genesis anthropogenic variants - agricultural, forestry, water management nature and road landscapes of anthropogenic landscapes.

Application of the regional-typological principle of research and the allocation of tracts in the objects mapping helps to visualise in the imageryiconic shape, morphological features, structural and genetic homogeneity of the research area and is an important and effective tool for the implementation of landscape diagnosis. The results of determination and analysis of the territorial organization promising to expand the areas of NNP, given the characteristics of the investigated landscape-typological units, is the most compelling basis in the planning and development of effective conservation of functionalterritorial structure.

Selected as a result of mapping, landscape complexes of tracts are the most typical for the study area, but the information does not exhaust all their landscape diversity and is both the basis and prerequisite for further detailed landscape studies, first of all the dynamics, development and evolution of landscapes. Given the limitations of the expeditionary method in collecting information from these areas of study, it would be logical to propose to consider planning, organizing, and conducting semistationary and stationary studies of the area to produce deeper and more detailed results. 


\section{References}

1. Diamond, J. Trump calls climate activists perennial prophets of doom during Davos economic forum [Electronic resource] / J. Diamond, N. Carvajal. - Available at : https://edition.cnn.com/2020/01/21/politics/donald-trump-davos-speechclimate-change/index.html

2. Roman-Palacios, C., Wiens, J. Recent responses to climate change reveal the drivers of species extinction and survival [Electronic resource] / C. Roman-Palacios, J. Wiens. - Available at: https://doi.org/10.1073/pnas.1913007117

3. Галущенко, С. Охраняемье природнье территории Европьы. Концепџия невмешательства [Электронньй ресурс] / C. Галущенко. - Режим доступа: http://ecoethics.ru/ohranyaemyie-prirodnyie-territorii-evropyi-kontseptsiyanevmeshatelstval

4. Гудзевич, А. Вінниччина: иифрри та факти [Текст] : навчальний посібник / А. Гудзевич, В. Любченко, I. Война. - Вінничя: ПП Балюк І.Б., 2018. - 320 c.

5. Гудзевич, А. Особливості формування природно-заповідної мережі Вінниччини [Текст] / А. Гудзевич // Екологічний контроль і моніторинг стану дубових лісів Поділля та особливості їх природного відновлення: М-ли I-ої Міжнародної науково-практичної конференції (20-22 травня 2015 року). - Вінниця: ФОП Корзун Д. Ю., 2015. - С. 11-15.

6. Европейская конвенциия о ландшафтах (20 октября 2000 г.) [Электронньй ресурс]. - Режим доступа: http://www.coe.int/t/dg4/ cultureheritage/heritage/landscape/versionsconvention/Russian.pdf

7. Брагин, П. Морфодинамический анализ топологии ландмафта как базовая операџия ландмафтного планирования: автореф. на соиск. научн. степени канд. геогр. наук. : спеи. 25.00.23. «Физическая география и биогеография, география почв и геохимия» [Текст] / П. Брагин. - Ярославль, 2005. - Режим доступа: http:/learthpapers.net/morfodinamicheskiy-analiztopologii-landshafta-kak-bazovaya-operatsiya-landshaftnogoplanirovaniya

8. Боков, В. Учет структуры и организации ландшафтов в планировочных решениях [Текст] / В. Боков, С. Карпенко // Актуальные проблемы ландшафтного планирования: Материаль всеросс. научн.-практ. конференции. - М.: Изд-во МГУ, 2011. - C. 29-33.

9. Природа Украинской ССР. Ландиафты и физико-географическое районирование [Текст] / А. Маринич, В. Пащенко, П. Шищенко. - Киев: Наукова думка, 1985. - 224 с.

10. Батуев, А. Обоснование и картографирование территориальной структуры экологического каркаса региона [Текст] / А. Батуев, Д. Лопаткин // Изв. Иркут. ун-та. Сер. «Науки о Земле». -2008. - Т. 1, № 1. - С. 56-75.

11. Asfaw, M. Quantification and mapping of the spatial landscape pattern and its planning and management implications a case study in Addis Ababa and the surrounding area, Ethiopiar [Electronic resource] / M. Asfaw, W. Hailu, K. Mengistie. Geology, Ecology, and Landscapes. https://doi.org/10.1080/24749508.2019.1701309

12. Максименко, Н. Ландшафтно-екологічне планування в інвайронментальному менеджменті територій локального рівня організаиії довкілля: автореф. дис. на здобуття наук. ступеня д-ра. геогр. наук : спец. 11.00.11 «Конструктивна географія і рачіональне використання природних ресурсів» [Текст] / Н. Максименко. - Харків: ХНУ, 2018. - 44 с.

13. Удовиченко, В. Конструктивно-географічні засади регіонального ландиафтного планування: теорія, методологія, практика (на прикладі Лівобережної полісько-лісостепової частини території України: дис. ... доктора географ. наук : спец. 11.00.11 [Текст] / Удовиченко Вікторія Віталіївна. - Київ: КНУ, 2018. - 563 с.

14. Гавриленко, О. Дослідження антропогенної трансформації сучасних ландшафтів України для иүілей геоекологічного обтрунтування системи природоохоронних заходів [Текст] / О. Гавриленко // Вісник Киїського національного університету імені Тараса Шевченка. Серія Географія. - 2004. - Вип. 49. - C. 12-15.

15. Гудзевич, А. Ландиафтна і біотична різноманітність проектованого Подільського начіонального природного парку [Текст] / А. Гудзевич // Екологічний вісник. - вересень-жовтень 2006. - №5 (39). - С. 2-4

16. Звіт з наукової теми: «Науково-пошукові роботи по забезпеченню підготовки матеріалів щзодо створення Чечельнищького національного природного парку» [Текст] / за заг. ред. А. Гудзевича. -№ д/p 4/17. - Вінниия, $1998 .-54$ c.

17. Гудзевич, А. Функиіональне зонування проектованого начіонального природного парку «Південне Поділля» [Текст] / А. Гудзевич // Наукові записки ТДПУ. - Серія Географія. - №2. - 2001. - С. 88-99.

18. Гудзевич, А. Особливості господарської зони проектованого національного природного парку на Вінничині [Текст] / А. Гудзевич // Наукові записки ТДПУ. - Серія Географія. - № 2. 2004. - С. 88-99.

19. Гудзевич, А. Просторово-часова організачія сучасних ландиафтів: теорія і практика [Текст] : монографія / А. Гудзевич. - Вінничя: Віндрук, 2012. - 232 c. +28 іл.

20. Проект організачії території Начіонального природного парку «Кармелюкове Поділля», охорони, відтворення та рекреаційного використання його природних комплексів та об'єктів [Текст] / ПрАТ «Наукововиробничий комплекс «Курс»; ПП «Центр екологічного управління». - Київ, 2016. - 236 с.

21. Кочергина, 3. Оченка ландиафтной структуры для целей землеустройства [Текст]: учеб. пособие / 3. Кочергина, И. Хоречко. - Омск : Изд-во ФГОУ ВПО ОмГАУ, 2007. - 120 с.

22. Landschaftsplanung. Inhalte und Verfahrensweisen. - Bonn: Bundesministerium fuer Umwelt, Naturschutz und Reaktorsicherheit. - 1997. - P. 18-23.

23. Ndubisi, F. Landscape ecological planning [Text] / F. Ndubisi // Ecological design and planning [eds. G.F. Thompson, F.R. Steiner]. - N. Y.: Wiley, 1997. - P. 9-44.

24. Petry, D. Landscape function assessment and regional planning: creating knowledge bases for sustainable landscape development [Text] / D. Petry //Landscape balance and landscape assessment. - Berlin: Springer, 2001. - P. 251-280.

25. Steiner, F. The living landscape: an ecological approach to landscape planning [Text] / F. Steiner. $-2 n d$ ed. $-N$. Y.: McGraw-Hill, 2000. - 477 p. 
26. Методические указания по ландшафтным исследованиям для сельскохозяйственных иелей [Текст] / [ред. Г. Швебс, П. Шищенко]. - М.: ВАСХНИЛ, 1990. - 58 c.

27. Методы комплексных физико-географических исследований [Текст] : учеб. пособие для студ. вузов / В. Жучкова, Э. Раковская. - М.: Академия, 2004. - 368 c.

28. Семенов, Ю. Картографирование геосистем для ландиафтного планирования районов Республики Алтай [Текст] Ю. Семенов, Г. Лысанова // География и природ. ресурсы. - 2016. - № 4. - С. 66-75.

29. Пересадько, В. Картографічне забезпечення екологічних досліджень і охорони природи [Текст]: монографія / В. Пересадько. - Харків: ХНУ ім. В. Н. Каразіна. 2009. - 242 с.

30. Ahern, J. Spatial concepts, planning strategies and future scenarios: a framework method for integrating landscape ecology and landscape planning [Text] / J. Ahern. - N. Y.: Springer, 1999. - P. 175-201.

31. Steinitz, C. A framework for planning practice and education [Text] / C. Steinitz // Ecological landscape planning [ed. M. Bunji]. - Tokyo: Process Architecture, 1995. - P. 42-54.

32. Wiensr, J. Scaling of «landscapes» in landscape ecology, or, landscape ecology from a beetle's perspective [Text] / J. Wiensr, B. Milne // Landscape Ecology. - USA New Mexico-Fort Collins: SPB Academic Publishing, 1989. - Vol. 3, No 2. - P. 87-96.

33. Удосконалена схема фізико-географічного районування України [Текст] / О. Маринич, Г. Пархоменко, О. Петренко, П. Шищенко // Украӥнський географічний журнал. - 2003. - №1. - С. 16-20.

34. National Atlas of Ukraine. Kyiv: DNVP Kartografiya, 2007.

Authors' Contribution: All authors have made an equal contribution to this work

UDC 911.5:913 (477.44)

Anatoliy Hudzevich,

Doctor of Sciences (Geography), Professor, Department of Geography, Vinnytsia Mykhailo Kotsiubynskyi State Pedagogical University,

32 Ostrozhskoho St., Vinnytsia, 21001, Ukraine,

e-mail: amarek@ua.fm, https://orcid.org/0000-0001-8884-9436;

Vasyl Liubchenko,

$\mathrm{PhD}$ (Geography), Head of the Research Department of the Karmelyukove Podillya National Nature Park,

15 Sviato-Mikhailivskia St., Chechelnyk village, 24800, Vinnytsia region, Ukraine, e-mail: vasalve@gmail.com, https://orcid.org/0000-0002-1871-5341;

\section{Lina Bronnikova,}

Senior Lecturer (Agriculture), Department of Agriculture, Soil Science and Agrochemistry

Vinnytsia National Agrarian University, 3 Soniachna St., Vinnytsia, 21100, Ukraine, e-mail: linabronnikova@gmail.com, https://orcid.org/0000-0002-1790-161X;

\section{Ludmila Hudzevich,}

$\mathrm{PhD}$ (Biology), Associate Professor, Department of Biology,

Vinnytsia Mykhailo Kotsiubynskyi State Pedagogical University, e-mail: gudzevichluda@gmail.com, https://orcid.org/0000-0002-7631-7704

\section{LANDSCAPE APPROACH TO REGIONAL FEATURES ORGANIZATION OF ENVIRONMENTAL MANAGEMENT OF THE PROTECTED AREA}

Formulation of the problem. The nature protection territories of Ukraine and Vinnytsia region in particular are experiencing the not best period of their development. This is reflected in the low indicators and the rate of development of the Nature Reserve Fund, which are lagging behind those declared in the programming documents and European norms.

Substantial expansion of already existent nature protection territories can help the decision of not simple problem and before everything level of national natural park.

The purpose of the article. The use of landscape analysis to form an idea of the territorial structure and physiognomic features of the landscape complexes of an economic area of a national nature park and adjacent areas to prevent the loss of their landscape and biodiversity. Research methods included field-based observations and mapping.

Results. The area under study for the extension of the Karmelyukove Podillya National Park belongs to the class of plain Eastern European landscapes. The general background of the forest-steppe complexes is formed by landscapes of elevated forest plains, strongly indented by ravines and gullies, with chernozems of podzolized. This type of landscapes is a consequence of the active development of erosion-denudation processes within the most hypsometrically elevated in the studied territory of the southeastern spurs of the Podolsk hills. The forest-steppe type includes three subtypes of landscapes: broad-leaved forest, rare-forested 
forest steppe, and meadow-steppe. The peculiarity of the manifestation and distribution of types of landscapes is caused by the fact that the areas of their location are intersected by intrasonal anthropogenic landscape complexes, the formation of which is caused by such types of nature management as forestry and agriculture. The consequence of age-old human activity is the formation of different classes of anthropogenic landscapes of agricultural, forestry, water management nature and road. The results of the research were used to create a map of the landscapes of the prospective territory for inclusion in the Karmelyukove Podillya National Park. Apart from high-level typological units (classes and types of landscapes), it presents 33 types of tracts, which are currently the most typical landscapes of the study sites. The information presented on the map does not exhaust their entire landscape diversity and is the basis for further detailed landscape studies.

The scientific novelty of the research is determined by the originality and detail of the information about the landscape structure of the national nature park, and its practical importance is determined by the possibility of using the results of landscape-cartographic analysis for the needs of optimizing the functioning of high-level nature protection institutions. Landscape justification for the expediency of including the studied area (text and map of landscapes of the «Vyshenka» tract and adjacent territory) was submitted to the Park administration for permanent use.

Keywords: landscape analysis, national nature park, landscape map, anthropogenic landscapes, tracts of terrain types.

\section{References}

1. Diamond, J., Carvajal, N. (2020). Trump calls climate activists perennial prophets of doom during Davos economic forum. Access mode: https://edition.cnn.com/2020/01/21/politics/donald-trump-davos-speech-climate-change/index.html

2. Roman-Palacios, C., Wiens, J. (2020). Recent responses to climate change reveal the drivers of species extinction and survival. Access mode: https://doi.org/10.1073/pnas.1913007117

3. Halushchenko, S. (2017). Okhraniaemie pryrodnie terrytoryy Evropi. Kontseptsyia nevmeshatelstva [Protected natural areas of Europe. The concept of non-interference]. Access mode : http://ecoethics.ru/ohranyaemyie-prirodnyie-territoriievropyi-kontseptsiya-nevmeshatelstval [in Ukrainian].

4. Hudzevich, A., Liubchenko, V., War, I. (2018). Vinnychchyna: tsyfry ta fakty [Vinnytsia region: figures and facts: a textbook]. Vinnytsia: PP Baliuk I.B. [in Ukrainian].

5. Hudzevych, A. (2015). Osoblyvosti formuvannia pryrodno-zapovidnoi merezhi Vinnychchyny [Features of formation of the nature reserve network of Vinnytsia region]. Ekolohichnyi kontrol i monitorynh stanu dubovykh lisiv Podillia ta osoblyvosti yikh pryrodnoho vidnovlennia: M-ly I-oi Mizhnarodnoi naukovo-praktychnoi konferentsii (20-22 travnia 2015 roku). Vinnytsia: FOP Korzun D. Yu, 11-15 [in Ukrainian].

6. Evropeyskaya konventsiya o landshaftah (20 oktyabrya 2000) [European Landscape Convention (October 20, 2000)]. Access mode: http://www.coe.int/t/dg4/cultureheritage/heritage/landscape/versionsconvention/Russian.pdf [in Russian].

7. Bragin, P. (2005). Morfodinamicheskiy analiz topologii landshafta kak bazovaya operatsiya landshaftnogo planirovaniya [Morphodynamic analysis of landscape topology as a basic operation of landscape planning]. Extended abstract of candidate's thesis. Yaroslavl. Access mode: http://earthpapers.net/morfodinamicheskiy-analiztopologii-landshafta-kak-bazovayaoperatsiya-landshaftnogo-planirovaniya [in Russian].

8. Bokov, V., Karpenko, S. (2011). Uchet strukturyi i organizatsii landshaftov v planirovochnyih resheniyah [Consideration of the structure and organization of landscapes in planning decisions]. Aktualnyie problemyi landshaftnogo planirovaniya - Actual problems of landscape planning: Materialyi vseross. nauchn.-prakt. konferentsii. (pp. 29-33). Moskva: Izd-vo MGU [in Russian].

9. Marinich, A., Paschenko, V., Shischenko, P. (1985). Priroda Ukrainskoy SSR. Landshaftyi i fiziko-geograficheskoe rayonirovanie [The nature of the Ukrainian SSR. Landscapes and physical-geographical zoning]. Kiev: Naukova dumka [in Ukrainian].

10. Batuev, A., Lopatkin, D. (2008). Obosnovanie i kartografirovanie territorialnoy strukturyi ekologicheskogo karkasa regiona [Justification and mapping of the territorial structure of the ecological framework of the region]. Izv. Irkut. un-ta. Ser. «Nauki o Zemle» - Izv. Irkut un-that. Ser. Earth Sciences (Vols. 1), 1, $56-75$ [in Russian].

11. Asfaw, M., Hailu, W., Mengistie, K. (2019). Quantification and mapping of the spatial landscape pattern and its planning and management implications a case study in Addis Ababa and the surrounding area, Ethiopia. Geology, Ecology, and Landscapes. https://doi.org/10.1080/24749508.2019.1701309

12. Maksymenko, $N$. (2018). Landshaftno-ekolohichne planuvannia $v$ invaironmentalnomu menedzhmenti terytorii lokalnoho rivnia orhanizatsii dovkillia [Landscape-ecological planning in environmental management of territories of local level of environmental organization]. Extended abstract of Doctor's thesis. Kharkiv: KhNU [in Ukrainian].

13. Udovychenko, V. (2018). Konstruktyvno-heohrafichni zasady rehionalnoho landshaftnoho planuvannia: teoriia, metodolohiia, praktyka (na prykladi Livoberezhnoi polisko-lisostepovoi chastyny terytorii Ukrainy [Structural-geographical bases of regional landscape planning: theory, methodology, practice (on the example of the Left-bank Polissio-forest-steppe part of the territory of Ukraine)]. Doctor's thesis. Kyiv: KNU, 2018 [in Ukrainian].

14. Havrylenko, O. (2004). Doslidzhennia antropohennoi transformatsii suchasnykh landshaftiv Ukrainy dlia tsilei heoekolohichnoho obgruntuvannia systemy pryrodookhoronnykh zakhodiv [Investigation of anthropogenic transformation of modern landscapes of Ukraine for the purposes of geo-ecological substantiation of the system of nature conservation measures]. 
Visnyk Kyivskoho natsionalnoho universytetu imeni Tarasa Shevchenka, Seriia Heohrafiia [Bulletin of Taras Shevchenko National University of Kyiv. Geography Series], 49, 12-15 [in Ukrainian].

15. Hudzevych, A. (2006). Landshaftna i biotychna riznomanitnist proektovanoho Podilskoho natsionalnoho pryrodnoho parku [Landscape and biodiversity of the projected Podilsky National Nature Park]. Ekolohichnyi visnyk, veresen-zhovten. Ecological Bulletin, 5 (39), 2-4 [in Ukrainian].

16. Zvit z naukovoi temy: «Naukovo-poshukovi roboty po zabezpechenniu pidhotovky materialiv shchodo stvorennia Chechelnytskoho natsionalnoho pryrodnoho parku» (1998). [Report on the scientific topic: «Research and development work to ensure the preparation of materials for the creation of the Chechelnitsky National Nature Park»]. Za zah. red. A.V. Hudzevycha. № d/r 4/17. Vinnytsia [in Ukrainian].

17. Hudzevych, A. (2001). Funktsionalne zonuvannia proektovanoho natsionalnoho pryrodnoho parku «Pivdenne Podillia» [Functional zoning of the projected South Podillya National Nature Park]. Naukovi zapysky TDPU - Scientific notes of TSPU , 2, 88-99 [in Ukrainian].

18. Hudzevych, A. (2004). Osoblyvosti hospodarskoi zony proektovanoho natsionalnoho pryrodnoho parku na Vinnychchyni [Features of the economic zone of the projected national natural park in Vinnytsia region]. Naukovi zapysky TDPU-Scientific notes of TSPU, Seriia Heohrafiia, № 2, 88-99 [in Ukrainian].

19. Hudzevych, A. (2012). Prostorovo-chasova orhanizatsiia suchasnykh landshaftiv: teoriia i praktyka [Spatio-temporal organization of modern landscapes: theory and practice].Vinnytsia: Vindruk [in Ukrainian].

20. Proekt orhanizatsii terytorii Natsionalnoho pryrodnoho parku «Karmeliukove Podillia», okhorony, vidtvorennia ta rekreatsiinoho vykorystannia yoho pryrodnykh kompleksiv ta obiektiv (2016). [The project of the organization of the territory of the Karmelyukovo Podillya National Nature Park, protection, reproduction and recreational use of its natural complexes and objects]. Kyiv [in Ukrainian].

21. Kocherhyna, Z., Khorechko, Y. (2007). Otsenka landshaftnoi strukturi dlia tselei zemleustroistva [Assessment of landscape structure for land use purposes]. Omsk: Yzd-vo FHOU VPO OmHAU [in Russian].

22. Landschaftsplanung (1997). Inhalte und Verfahrensweisen. Bonn, Bundesministerium fuer Umwelt, Naturschutz und Reaktorsicherheit, 18-23.

23. Ndubisi, F., eds. Thompson, G.F., Steiner, F.R. (1997). Landscape ecological planning. Ecological design and planning. N.Y.: Wiley, 9-44.

24. Petry, D. (2001). Landscape function assessment and regional planning: creating knowledge bases for sustainable landscape development. Landscape balance and landscape assessment. Berlin, Springer, 251-280.

25. Steiner, F. (2000). The living landscape: an ecological approach to landscape planning. 2nd ed. N. Y.: McGraw-Hill.

26. Shvebs, H., Shyshchenko, P. (1990). Metodycheskye ukazanyia po landshaftnim yssledovanyiam dlia selskokhoziaistvennikh tselei [Guidelines for Landscape Research for Agricultural Purposes]. Moskva: VASKHNYL [in Russian].

27. Zhuchkova, V., Rakovskaia, Ye. (2004). Metodi kompleksnikh fyzyko-heohrafycheskykh yssledovanyi [Methods of complex physical-geographical studies]. Moskva: Akademyia [in Russian].

28. Semenov, Yu., Lyisanova, G. (2016). Kartohrafyrovanye heosystem dlia landshaftnoho planyrovanyia raionov Respublyky Altai [Mapping of geosystems for landscape planning of regions of the Altai Republic]. Heohrafyia y pryrod. Resursi-Geography and natures. resources, 4, 66-75 [in Russian].

29. Peresadko, V. (2009). Kartohrafichne zabezpechennia ekolohichnykh doslidzhen i okhorony pryrody [Cartographic support for environmental research and nature conservation]. Kharkiv: KhNU im. V. N. Karazina [in Ukrainian].

30. Ahern, J. (1999). Spatial concepts, planning strategies and future scenarios: a framework method for integrating landscape ecology and landscape planning. N.Y.: Springer, 175-201.

31. Steinitz, C., ed. Bunji, M. (1995). A framework for planning practice and education. Ecological landscape planning. Tokyo, Process Architecture, 42-54.

32. Wiensr, J., Milne, B. (1989). Scaling of «landscapes» in landscape ecology, or, landscape ecology from a beetle's perspective. Landscape Ecology. USA New Mexico - Fort Collins, SPB Academic Publishing, 3, 2, 87-96.

33. Marynych, O., Parkhomenko, H., Petrenko, O., Shyshchenko P. (2003). Udoskonalena skhema fizyko-heohrafichnoho raionuvannia Ukrainy [The scheme of physical-geographical zoning of Ukraine has been improved]. Ukrainskyi heohrafichnyi zhurnal-Ukrainian Geographical Magazine, 1, 16-20 [in Ukrainian].

34. National Atlas of Ukraine (2007). Kyiv: DNVP Kartografiya [in Ukrainian]. 